\begin{tabular}{l} 
RCCS \\
\hline Annual Review
\end{tabular}

\section{RCCS Annual Review}

A selection from the Portuguese journal Revista Crítica de Ciências Sociais

4 | 2012

Issue no. 4

\title{
The State and the Market: An Institutionalist and Relational Take
}

\section{José Reis}

Translator. João Paulo Moreira

\section{OpenEdition}

\section{Journals}

Electronic version

URL: http://journals.openedition.org/rccsar/433

DOI: $10.4000 /$ rccsar.433

ISSN: $1647-3175$

Publisher

Centro de Estudos Sociais da Universidade de Coimbra

Electronic reference

José Reis, "The State and the Market: An Institutionalist and Relational Take », RCCS Annual Review

[Online], 4 | 2012, Online since 01 October 2012, connection on 19 April 2019. URL : http://

journals.openedition.org/rccsar/433; DOI : 10.4000/rccsar.433

(C) CES 


\title{
José Reis
}

School of Economics and Center for Social Studies, University of Coimbra, Portugal

\section{The State and the Market: An Institutionalist and Relational Take ${ }^{*}$}

\begin{abstract}
State-market relations call for a holistic view of the relationship between the material and relational dynamics of society, on the one hand, and between these dynamics and institutional dynamics on the other. As the institution-of-institutions, the state contains mechanisms that are essential to the existence of markets themselves, and these mechanisms are not "natural" givens. It is therefore a mistake to conceive of the state, the market and society as opposing entities. One should turn instead to the institutionalist perspective, which draws from Polanyi, in order to offer a political approach to the state and the market. Economies are actually institutional production systems wherein the material density of the state both as organization and administration is of relevance. The institutionalist perspective thus needs to be fine-tuned in order to show that the state is more than a political-legal entity. That is one of the main goals of the present article.
\end{abstract}

Keywords: state; political economy; institutionalism; institutions; market; state-market relation.

I venture to think that modern economic life is seen much more clearly when [there is an] effort to see it whole. John Kenneth Galbraith, The New Industrial State (1967: 7)

\section{Introduction}

When, in The Theory of Moral Sentiments (1759), Adam Smith speaks of the conditions under which we approve of the actions of others, he alludes to certain moral attributes, such as sympathy and solidarity, that are inherent in the consenting subject. But he also points out that the actions deserving moral approbation must be in accordance with "general rules" and with "a system of behaviour which tends to promote the happiness either of the individual or of the society." Then Smith goes on to explain that in that case what we have before us is "a beauty [...] not unlike that which we ascribe to any well-contrived machine" (Smith, 2011: 291).

We can say then that our relationship with others involves both our subjective motives (let us call them our identity) and circumstances resulting from those principles that transcend us as individuals (we will call them alterity). As was only to be expected, the author of The Wealth of Nations - where many found nothing but the cold mechanics of the division of labor and the principles of self-interest and incentive-driven action, seeing these

\footnotetext{
* Article published in RCCS 95 (December 2011).
} 
as a solid enough foundation for a market society - turns out to be deeper and more complex than some of his interpreters.

My initial mention of a classic misconstrued by the liberal vulgate is not intended as a literal argument for discussing the contemporary problems posed by the state-market relation. ${ }^{1}$ It is however an argument intended to lay down some of the terms that no discussion of the complexity of collective life can afford to ignore. Most of all, it is a reminder of the fact that the mechanisms of action and decision are not unique, and that one should view them as plural and diverse.

That is why I will adhere to the notion that there are problems that call for a holistic view, truly a whole philosophy of collective life that may serve as a frame of reference for understanding and bringing together processes of a diverse nature, which may prove hard to consider in a segmented fashion. Of course this is only to be expected when one is dealing with the state, given that the latter is essentially a political entity and given also that, for that same reason, it expresses in the broadest terms society's organization and historical course.

In fact, in order to understand the state's underlying matrix we need a narrative of the relationship between the material and relational dynamics of society, on the one hand, and between these dynamics and the institutional dynamics on the other. At the same time, we need a view of the meaning of collective life beyond individual rationality and strictly selfinterested behavior. Besides, we have to see the state as the most complex institutional entity of all - I shall call it the institution-of-institutions - and as such it possesses a unique organizational density as well as a strong capacity to act back on the circumstances that shaped it and gave it meaning in the first place. Thus, one is bound to quickly find an intrinsic relationship between the state and the market, rather than the antinomy that often tends to be thrown our way.

Efforts aimed at capturing complexity are epistemological in nature, in that they are predicated on knowledge and on the conditions under which it is produced. But they are also ontological (or thematic), in that they reflect on the whole question of being, on the life process and specific organization processes. Let me stress this point, because contemporary circumstances tend to strongly reinforce the interdependencies between epistemological discussion and ontological attention. The enormous complexity of society's interactions is

\footnotetext{
${ }^{1}$ The present text is largely based on ideas already explored in Reis (2012).
} 
indeed at odds with a segmented view of the social organization, thus making all too clear how flimsy partial perspectives tend to be.

It is my contention that state and market ontologies are a particularly clear indication of that complexity, and that at the same time they strongly contribute to reinforce it, given the state's many important roles and functions as a result of the sharp acceleration of history in the $20^{\text {th }}$ century.

While it is true that the theme of state and market is just one among many topics at our disposal for an approach that allows us to overcome dichotomies, it can be argued that this is a unique endeavor in that it also stems from a unique obstacle: the presence, in economic thinking, of a markedly "separatist" influence that regards the state, the market and society in general as opposite entities. Most often than not, this view borders on what I see as basically an ideological prejudice. This perspective conceives of the state as a "problem" visà-vis society, while viewing the market as a "solution." As is well known, this stance grants society and the market the status of favored or even exclusive sites for entrepreneurialism, dynamism and freedom, while all it expects from the state is a normalizing role, in other words, that it acts as a constraint on the creative spirit. This mindset is a powerful obstacle to a relational conception of the state, which is why the argument put forward in the present paper is two-fold. Simply put, one might say that one part of the argument focuses on social evolution, with more attention thus being paid to relations between social and economic evolution, on one hand, and the shape, place and role of the state, on the other. The other part gives emphasis to the nature of the state as an institution, linking this debate to the role conferred on institutions as shapers of economic and social dynamics. My ultimate goal is, of course, to highlight the relational perspective proffered in this paper.

\section{The liberal take: Too central a place in economic thought}

It goes without saying that a given concept of the state always entails a corresponding, symmetrical concept of markets - and vice-versa. The reduction of the debate to a simple duality is perhaps the first problem we encounter, because such a dyad is certainly not apt to lead to an adequate analysis of the complexity of the forms of governance in contemporary societies, where the state and the market exist side by side with other coordination mechanisms such as networks, communities, business hierarchies and associations. But for the present purposes, we can just assume that this is a minor issue. 
Let us then start from that duality so as to get to the main debate and to the critique of the separatist perceptions of state-market relations. This is actually the context in which one ordinarily finds two basic - and rather disputable - positions concerning the place and role of markets. The first of these positions assumes that markets are morally neutral and that therefore they are a general device for resource allocation whose efficacy is to be assessed according to existing circumstances. The second is premised on the notion that markets are more than that: they are an essential, preeminent social mechanism, whose many virtues have manifested themselves over the course of history with civilizing effects, and currently serve as the foundation for the autonomy and freedom of individuals.

Given their quasi-naturalistic character, markets (a synonym for the economy as a whole, according to this reductionist view) are the locus of depoliticized relations. As such, they get to define the economy. What lies beyond them is the realm of politics, an altogether separate sphere. Nevertheless, a significant reversal of the initial argument turned the market into the site from which everything must derive, politics included, with the further understanding that its "laws" shall determine social behaviors as well as the behavior of states. For this reason, we are currently living in a time when a powerful rhetoric of persuasion of this kind, now seemingly at its peak, seeks to contaminate every single human option and to advance the idea that it is social and political options as well as forms of organization that have to bow before the insurmountable restrictions posed by markets, rather than the other way around.

Still, at the root of the most widely propagated views on state-market relations to be found in mainstream economic science there lies a contractualist notion that takes the market's natural virtues for granted and sees the state as an unnatural entity stemming from a strict delegation of powers by citizens. This is the liberal take, which rests on a theory of the state based on notions of property rights and transaction costs. According to this view, the state is essentially the product of a contract between legislator and constituent. Therefore, the constitution should limit itself to defining a framework of property rights, the role of the state being to enforce those rights while minimizing transaction costs. ${ }^{2}$ The citizens themselves are not in a position to enforce this goal, for they are aware of the radical uncertainty enveloping them as individuals. As a result, institutional choices are

\footnotetext{
${ }^{2}$ In other words, the social, political or regulatory arrangements required to attain the desired goals.
} 
based on contractualism, which in turn derives from an estimation regarding uncertainty and the need to guard against it. Therefore, citizens establish constitutional authorizations, i.e., they grant a mandate whereby institutions take on a supervision or prevention role on behalf of those who feel unsure about controlling their future situation. There is then, at the outset, a founding act on the part of citizens, who decide to delegate authority to a supreme legislator, freedom and security being their reward (as they benefit from the economies of scale resulting from collective delegation): a decision on the part of citizens, who "abstain from all attention to [...] personal wealth," as Humboldt put it in 1792 (qtd. by Furubotn and Richter, 2001). The state is thus the product of a self-imposed agreement aimed at freeing the virtues of the market and society and also, through a strict containment of politics within the confines of the state, at defending the depoliticized nature of the market itself. Supposedly the separation of the two spheres would then be consummated.

This initial liberal view, however, was soon "revised" to make way for another more mundane one, which saw the state-market relation as a relationship between "goodness" (or virtue) and "perversity" (or evil). In this light, the state, which had been born in purity by way of the initial contract, was soon to become an entity appropriated by rent-seeking, selfseeking politicians and bureaucrats. As a consequence, it started acting and being perceived as an intensely "politicized" space rather than as the initial legislator. According to such a view, modern states turned out to be markedly prone to illegitimacy and to overstepping their role and attributions. Thus the state emerges as both a construct formed by individuals - who are aware of the limits allotted to them by their own uncertainty - and an agent that is plainly aware of its own interests, which it tends to replicate in spite of its creators. The state we eventually come to encounter in the theories is therefore neither a eunuch-state nor a benevolent, tolerant decision-maker. It is rather a wicked or perverse state, which soon evaded the grasp of the individuals who created it. The perversity of the state is the perversity of its agents, functionaries and politicians, who quickly find out that they can become rent-seekers.

It is to public choice research ${ }^{3}$ that we owe a theory of bureaucracy. In addressing the basic question of how individual preferences that are necessarily different become

\footnotetext{
3 "The most recent source of public choice theory can be traced to six now classic studies written by a number of economists and one political scientist in the late fifties and early sixties" (Pereira, 1997: 420). See Duncan Black (1958), James Buchanan and Gordon Tullock (1962), Mancur Olson (1965), Kenneth Arrow (1951),
} 
reconciled in political institutions, the research shifted its focus to the offer of public goods to formulate the theory, repeating ad nauseam the arguments on the autonomy of the state, its separateness from society and the cumulative divergence between social and state preferences. The mechanism of this divergence rests on the simple fact that officials and politicians turn their own preferences (their personal interest in power, which they seek to self-replicate) into policies, which is why the state is nothing but the "parallelogram" of its agents' interests. In this light, for instance, social policies are perverse mechanisms that exist because they give the bureaucrats in charge of managing them the assurance that their posts and their status will remain untouched. The intrinsic aims of those policies do not much matter, then. There may be a good underlying idea to start with, which however is soon subverted and turned into perverse solutions. This notion has been aptly dissected in A. Hirschman's critique of the "rhetoric of reaction" (1991). ${ }^{4}$

A broader field than the one just described is that of constitutional economics (see Reis, 2009: 95-117). Built on a solid theoretical basis, it represents a vision with an interest in politics (or rather in political processes, to be exact), in the state and in the fact that societies are organized around a complex, intricate institutional structure. But the focal points of constitutional economics are individuals and their downright subjective behavior. Here, too, neither the state nor politics are viewed as entities or circumstances that one is required to understand in a collective, historical or process-related manner. Interpreting the intricate relationships between life's complexity and institutional forms is not a problem constitutional economics deals with. The economic theory of constitutions on which it is based must be understood as a mere procedure for understanding how individual preferences can be "amalgamated" to generate collective results. At stake, again, is a contractualist notion, which seeks the "reasons for norms." It is a notion built in the midst of a fierce debate at once against Keynesianism, against the maximizing paradigm and against the idea that there are external scales of value, exogenous to individuals, which constitute a pre-existing social pattern by which individual decisions are to be measured (e.g. a social utility function). The individualistic faith inherent in the constitutional reading is plainly

Anthony Downs (1957) and William Riker (1962). "These studies tend to be seen as the foundation of two research programs that, despite their separate nature, have been linked ever since: public choice theory and social choice theory, the latter having followed an autonomous path in the wake of the work of K. Arrow and Amartya Sen [...] while maintaining a close relationship with public choice" (ibidem).

${ }^{4}$ See Reis and Nunes (1993). 
manifest in the assumption that, "at least to a point and within certain limits," individuals actually choose their own restrictions. ${ }^{5}$

James M. Buchanan is a reference in this particular field. ${ }^{6}$ A founder of public choice theory, he laid out, in Constitutional Economics, an elegant, sophisticated construction of economic constitutionalism. There, the basic philosophical reasons behind his take-it-orleave-it argument are fully explained, but the elegance of the proposal is not lost on those who reject it. More than anybody else, Buchanan stated the firm belief, later turned into doctrine, that "the autonomous individual is not only presumed to exist; this individual is also presumed to be capable of choosing among alternatives in a sufficiently orderly manner as to allow a quality of rationality to be attributed to observed behavior" (Buchanan, 1991: 15).

But this view was soon turned into a trivial political economy of the welfare state. ${ }^{7}$ This is because, prior to the most elaborate developments of a theory of the state, what we find is the argument that, in practice, any form of state to which an authorization has been given is eventually liable to violate and abuse it, as institutions responsible for managing transfers to citizens suffer from a "natural" tendency towards growth. Such an argument amounts mostly to a prejudice. The belief that institutions are incapable of respecting boundaries because it goes against the incentives of political activity is in fact one of the grounding notions of contractarians when they set out to reflect on the institutional sphere. The truth is that welfare policies are carried out by normal, ordinary politicians whose autonomous interests are not in line with, and in fact subvert, the goal of individual autonomy underlying the interactions that shape the economy as-an-order (which in turn leads to the contradiction that not all individuals are... truly individuals after all).

\footnotetext{
${ }^{5}$ Alternatively put, it is all about "closing" the systems within which behaviors occur (Neves, 2004). Open systems exist when the restrictions that delimit decisions are perceived as exogenous, i.e., as coming from the outside.

${ }^{6}$ This conservative economist who launched, as early as the 1950s, a fiercely anti-Keynesian, openly political university movement aimed at the study of the free society, is primarily known as one of the founders of the public choice school. The Nobel Prize for Economics that he was awarded in 1986 symbolized the consecration, by Stockholm, of the decade's academic neoliberalism.

7 Buchanan's proposal regarding the "dismantling" of the welfare state is also extremely perplexing, illustrating the theory's 'wildest' facets. This is the case of the claim for the superiority of a form of organization of the economy that does not deal collectively with issues such as retirement pensions. Payment should then consist of a settlement of accounts with social security net contributors and net debtors, so as to reduce every single generation to a situation of equality and to abolish all management by the state, which is intertemporal by nature (Buchanan, 1986: 178-185).
} 
These were the reasons why the liberal program soon moved from the notion of contract to the need to revise and restrict the initial contract itself. This, as is well known, is what the attempts to shrink and dismantle the state are all about, mainly with regard to the social state and its commitment to building policies for strengthening state-society relations.

\section{The institutionalist debate on the state: The notion of the market as a political construct}

The assumption that the state is the exclusive seat of politics, whereas the market and the economy are depoliticized entities, has been the object of severe criticism. One such critique and alternative view is that of Ha-Joon Chang (2001), who claims that the political approach should be applied to both the state and the market. The political dimension is surely bound to prove more relevant in the relationship between the two.

Drawing from the pathbreaking work of, among others, Karl Polanyi, according to whom the "road to the free market was opened and kept open by an enormous increase in continuous, centrally organized and controlled interventionism" (1957: 140), Chang points to an approach centered on an institutionalist political economy that is capable of shedding light on the market's institutional complexity and especially on the fact that markets are definitely political constructs, as opposed to natural states or givens on which the lives of individuals and communities are built. They are political constructs because property rights, along with the other rights defining the conditions of market participation, become artifacts that are established by way of power relations, of forms of legitimation and of legal, political and institutional arrangements without which they would not exist. From primitive capitalist accumulation to contemporary forms of privatization, they are truly the result of a "highly political exercise" (Chang, 2001: 11).

Institutional complexity is also attested to by "the institutional diversity of capitalism," that is, by the various forms of articulation between the state, the market and other institutions. Historically, the absence of a general rule or pattern is shown by the various forms of political mediation at the basis of a number of different models, such as the Bismarckian welfare state in Germany, France's post-war industrial state, or Asia's developmentalist states. The liberal proposals for depoliticizing the market and the economy are therefore "at best self-contradictory and at worst dishonest" (ibidem). By the same token, the post-communist transitions have fully laid bare the limits of simplistic views of the market. In the absence of a structured as well as structuring state, the market failed to 
operate in a spontaneous manner, while there was clear evidence that the circulation of goods and services and the achievement of property rights took a perverse turn involving violence, corruption and the black market (Chang and Nolan, 1995; Stiglitz, 1999).

Thus, when the studies on the "varieties of capitalism" emphasize the differences and specificities of certain models of development, they stress the fact that such differences stem from particular institutional designs, which is what determines the features of, say, "market-coordinated" or "centrally coordinated" economies (Hall and Soskice, 2001). In fact, economies are institutional production systems (Hollingsworth and Boyer, 1997), which means that the pillars on which the workings of each of its particular forms rest (the financial system, the prevalent mode of corporate governance, business to business relations, industrial relations, the education and training systems, the organization of work, the state, or the innovation systems) take on certain particularities that extend to the relationships between them (Jackson and Deeg, 2006). Hence the notion that the roads to development require that the appropriate institutional arrangements be chosen (Rodrik, 2008). This might initially involve the right combinations of state and market, or, to be more exact, institutional arrangements that can be progressively deepened, leading to a reinvigoration of the economy and society, and which may even "deflect" the forces that push towards mere dilution in the world economy.

The institutions that make up and surround the market are therefore as numerous as they are diverse. They can be either formal, like law or state regulation, or informal, as is the case of social conventions or cultural practices, but they can also be self-imposed norms, as exemplified by associations and networks. Consequently, the limitations (or even distortions) of the liberal view can only be overcome by abandoning their "most crucial assumption," namely individualistic self-sufficiency, and replacing it with a "more complex view of the interrelationship between motivation, behaviour and institutions" (Chang, 2001: 18).

In order to fully capture the meaning of this statement, suffice it to consider two crucial variables of the entire economy: wages and interest rates. Both "are politically determined to a very large degree. Wages are politically modified not simply by minimum wage legislation, but also by various regulations regarding union activities, labour standards, welfare entitlements and, most importantly, immigration control" (ibidem: 12). 
Such a fundamental divide between politics and the economy makes little sense, then, for analyzing the framework within which contemporary societies operate. Neither is the state the stronghold of politics (and social elaborations), nor is the economy exclusively made up of the market, or a depoliticized entity that can be objectified in a set of "natural" relationships corresponding to the exchanges and transactions that make it possible. Thus the state is not necessarily an obstacle to the market, but rather, and most of all, one of the entities that make it feasible.

Viewed in this light, the historical experiences of development, namely with regard to today's wealthier nations, show the vast occurrence of different forms of interventionism, thus disproving the liberal narrative according to which intervention should be kept to a minimum because "the pricing system is an efficient mechanism of resource allocation" and "development will come about naturally as long as the adequate conditions for private investment are in place" (Mamede, 2009: 179-180). Quite to the contrary, there are issues of large production scales which are needed to make static economies of scale possible and which demand high upfront investments. Also needed are larger markets or processes for making those "economies of scale more dynamic," either through economies of learning or by "overcoming production coordination failures" - in a word, pretty much everything warrants state intervention (ibidem: 182-184).

\section{The complex gamut of roles played by the socially embedded state: Basis, action and trajectory}

The social use of the state is therefore not limited to an abstract, contractualist notion established by self-sufficient individuals bent on confining their action to a depoliticized reserve, be it called market or economy. The very fact that the market is a construct entails the existence of a dense institutional complexity that genetically connects it with the state. Besides, the state's role is not just a matter of overcoming "market failures," as the neoclassical theory sees it. Contrary to what Chang, in a sense, suggests, it also seems fair to say that the modern states of developed or developing capitalist societies do not have to be seen as strictly institutional entities, i.e., as entities that define essential political relationships, namely those that build the market and make it possible. Admittedly, Chang sees the state, first and foremost, as a participant in the construction of individual motivations: in line with institutionalist thinking, he "does not see these motivations as given 
but as being fundamentally shaped by the institutions surrounding the individuals" (Chang, 2001: 17). Consequently, his purpose - a very useful one at that - is to show "how an 'institutionalist' analysis of the relationship between motivation, behaviour and institutions may improve our thinking about the role of the state" (ibidem). Still, one must agree that the state is more than that: it is a full-fledged, materially dense institution that makes its presence felt not only in political terms or in terms of the shaping of individual behaviors, but also at the economic and social level. It does not just define the feasibility of relationships in society, it is part and parcel of those relationships.

Hence my suggestion is that, in order to correctly interpret the process of market construction, a distinction be made between the notion of institutional political construction (my representation of Chang's proposal) and that of material and relational political institution, based on a tight web of roles played by the state in both the economy and society. It is the purpose of my suggestion to capture the relationship between social dynamics and institutional arrangements. At the same time, it aims to stress the fact that institutions play a materially active role themselves, and therefore are not mere means of politically validating that which is spontaneously generated by society.

As we can see, the role of the state in the economy and in society, together with its institutional significance, has a strong material density and is a product of historical evolution. Furthermore, that role is mostly the outcome of social tensions that need to be resolved either by agreement or compromise, and once the solution is achieved it becomes a new basis for subsequent social dynamics. In addition, although it is a product of historical dynamics, the role of the state forms a hierarchical relationship. Thus, the state is not just present in social or contractual interactions, it also shapes collective dynamics as well as defines a certain relational order, by way of the legitimacy it acquires and the power that defines it.

The truth is that the modern state performs a complex range of actions, and for this reason its material role as a shaper of economies cannot be understood by merely emphasizing how markets are institutional political constructs that depend on the state's legal framework. The social uses of the state in this kind of society show the existence of a tight web of forms of action. The state establishes and sanctions certain hierarchical patterns of collective action (pursuant to what was said above with regard to economies of scale and of learning as well as production coordination), and defines and redefines the public and 
private domains. This is done with recourse to a variety of roles not limited to the law, to regulatory instruments or to its political role, but also by means of substantive policies, both long-consolidated - such as the policies structuring the provision of education, health and social care services - and those that pertain to the modern structuring of societies - e.g. in areas such as urban space, mobility, science, and spatial planning and development. But given their dimension and shape, markets are related to and dependent on the substantive role played by the state, and not just on its strictly political function. Here we might resume our dialogue with Chang in order to take note of his analysis - albeit in a different context than the one addressed above - of the role of state-owned enterprises with regard to correcting market deficiencies and building long-term development relationships, especially in less developed countries (Chang, 2007).

While it is true that the state's functions in terms of power and domination are historically dynamic and evolving, there are perhaps three aspects that illustrate the density of public actions, beside and beyond the strictly political arena within which the statemarket relationship has been described above. First of all, the state defines and consolidates collective infrastructures to ensure proper social functioning and innovation. This is arguably the foundation from which societies, economies and markets grow. Second - and on a level that is no longer fundamentally material in nature - the state, by virtue of principles that it itself promotes (such as the choice between public or private solutions for society's problems) exerts an influence on the collective patterns of social and economic performance. This, in itself, evinces the presence of the state in, or its relationship with, the actual workings of society and the economy. Third and last, the state (even in its historical attempts to shrink to a minimal state) embodies strategic orientations, i.e., it plays an active role in shaping trajectories. In short, the state can be seen as an essential actor in the formation of a certain relational order, as well as the principal agent in the creation of externalities in the economy. While the latter role is commonly acknowledged, it also seems evident that the former, located somewhere between the state's material and political functions, is no less important.

The centrality of the state in the economy is especially significant whenever it plays a major role in structuring the behavior of the social actors and the relationships between them. In truth, the public expenditure burden on the GDP and the entire range of economic means owned by the state are not the sole indicators of its importance, for the roles of the 
state also include establishing contexts for action, setting meanings, and building consensus (Reis, 2001). There is thus an implied contractuality in the relations between the state and the economy, but this particular type of contractuality, which I term relational order, is radically different from the one underlying the liberal views critiqued above. Proof of this role of the state is not to be found in statistics, nor can it be arithmetically deduced, for it is intimately connected with an interpretation of relational dynamics. So for instance, when the need arises for creating a structure of social rights (such as trade union rights, employment rights, wage entitlements, welfare and health rights) or for enhancing the qualifications of future generations (namely with regard to education and training), one concludes that the state plays a fostering role which serves as a basis for development processes. The stabilization of macroeconomic variables, whenever necessary, is basically an exclusive attribute of the state, because when it comes to regulate external monetary relations, to ensure exchange capabilities, to take credit enhancement measures, to set up a framework for production and consumption, and even to safeguard productive capacity, it all takes place, more often than not, in the absence of strong - let alone autonomous and constructive - social partners.

The state, therefore, is a generator of externalities. ${ }^{8}$ The production of fixed social capital, of modern infrastructures, the development of skills and qualifications among the population, is quite a vast area in which the state materially fulfills its function. It is only understandable that this is the case in periods and under circumstances in which there are obstacles to the processes of social and political democratization, with not only social rights and human skills but also infrastructural modernization making that fixed social capital a pressing need. The former comprise health, education and training infrastructures. The latter includes mobility, urban well-being and personal well-being structures, as well as the material contexts for the functioning of businesses. One can only begin to imagine how decisive this role of the state has been in such periods.

What makes state-society relations a predominantly relational issue is that, alongside the state's "autonomous" role, there are also diffuse social dynamics requiring an involvement on the part of the state. This relationship between a relatively diffuse dynamic evolution and

\footnotetext{
${ }^{8}$ In economic terms, a positive externality describes the production of advantages in a way that transcends the agents most directly associated with it and that benefits all the agents involved without it affecting the price system.
} 
formal structuring strikes me as crucial for understanding the relationship between the state and society. J. K. Galbraith expressed in an original way the lines along which this dialectic operates. In The Affluent Society (1958), he discusses the processes and ways "of obtaining and then of maintaining a balance in the great flow of goods and services with which our wealth each year rewards us" (1998: 223). Alluding to progress and social evolution as a diffuse process, Galbraith deals mostly with the private production sector. But he does point out that "In the meantime, there are large ready-made needs for schools, hospitals, slum clearance and urban redevelopment, sanitation, parks, playgrounds, police and other pressing public services. Of these needs, almost no one must be persuaded" (ibidem). The basic tenet here is that "[f]ailure to keep public services in minimal relation to private production and use of goods is a cause of social disorder or impairs economic performance" (ibidem: 193).

Still, one could say that Galbraith's input serves to establish the two poles of the relational dynamics. That is why, contrary to those views that grant full sovereignty to the individual, ${ }^{9}$ he prefers - as he puts it in The New Industrial State - to analyze "a formidable apparatus of method and motivation causing its reversal" (1968: 264). For that purpose he turns his attention to the "technostructure" that surrounds and drives the large corporations, to whose "needs and conveniences" markets, "far from being the controlling power in the economy, were more and more accommodated" (ibidem: vii). It is clear that this "industrial state" amounts to a lot more than a political body: is a complex of tight relationships between the public and private spheres. In its size and substance, the private economy separates itself radically from the individual and from the normative conception of the market to take on an institutional character. Both in the process of generating the possibilities at the root of these circumstances and in the validation of their subsequent action, the borders delimiting the state and the market tend to blur and become porous.

\section{Reconsidering the problem in the face of a fundamental crisis}

The above considerations are all the more pressing in the face of the current crisis, which, given the nature of the break between economic domains and economic aggregates, I prefer to call a fundamental crisis. In fact, theoretical notions and ontologies of the state and the

\footnotetext{
${ }^{9}$ In this context, Galbraith problematizes the liberal notion of "consumer sovereignty."
} 
market are not the only topics worthy of discussion and reflection. The powerful process whereby the economy's substantive relationships were reconfigured did more than just assign the markets a disproportionate role: it highlighted the redefinition of a number of categories that are vital for any discussion of the state-market relationship. It is actually the notion of economy, or economic system, that needs to be deeply grasped. This has always been the case, but it is not wrong to say that it has become more relevant in view of the turbulent circumstances the world has been facing since at least 2008, when the severity of the crisis became all too clear. Our questions about what constitutes the economy and about its goals should bring us to the idea that the economy is a system for the provision and use of goods and services and aimed at initiating processes conducive to the creation of wellbeing and the improvement of human skills, both at the individual and collective level. So neither markets nor the economy are a simple, rule-free game involving assertion of interests, the interpretation of motives or the erratic doling out of either incentives or sanctions. If you have an individualistic understanding of the economy and see it in terms of competitive relations based on egotism and self-interest, you are likely to fare well with those narrow definitions of economic systems and even of economics that focus on a maximizing, normative concept of individual rationality and on reducing the entire range of social mechanisms for resource allocation and economic coordination to just one - to wit, the markets game.

We are only too familiar with the tumultuous circumstances of these times of ours, brought about by the financialization of the world economy: the handing over of international financing and credit to liberalized markets and to speculation triggered a financial crisis which turned into a profound and predictably protracted economic crisis as soon as the turbulence hit the freewheeling banking system. It is nevertheless worth recalling, if only briefly, that at a deeper level we were - and still are - faced with two inescapable phenomena. One is the fact that the social function of credit and financing became radically disconnected from the economy and from the goals of wealth creation and promotion of individual and collective skills, favoring the autonomization of uncontrolled financial intermediation and speculation instead. What ought to be instrumental became the source of rules and assumed the power to rule.

The second, perhaps deeper, phenomenon was a consequence of the actual disconnect of the economy vis-à-vis society. The economy, as defined above, has to be conceived of as 
intimately connected to society. In other words, the economy cannot be oblivious to the plurality of individuals and organizations and to the cultural and institutional patterns established by them, nor can it ignore the compromises and goals resulting from the conflicts and agreements generated by human communities. But we know that this relationship was reversed when a normative, reductive view of the economy - as opposed to one where the economy and society coexist in a positive relationship - started to gain the upper hand.

This dual process of "disengagement" was the cause of widespread instances of unsustainability which are no longer limited to the financial sector, as they touch upon the economic and social, not to mention environmental, domains as well. It does seem obvious that the whole framework for the movement and availability of capital has evaded both adequate forms of regulation and the judicious presence of a variety of mechanisms for allocating resources, with the ensuing weakening of the public sphere. Instead of that, we moved towards a single, totalizing and certainly totalitarian solution - that of "endless markets." As João Rodrigues (2009: 57 ff.) says, the conversion of what Polanyi termed fictitious commodities (labor, nature, land and the monetary-financial system) into simple commodities ought to be considered as the deepest, most substantive process in the redefinition of the framework of contemporary economic relations, in that it undermined the notion of economy I described above and brought about a fundamental crisis in the relations that had led to the stabilization of capitalism as a production system over the last six decades. The most visible outcome of it all was the proliferation of turbulent situations in which irrationalities broke loose, inequalities were fostered, peripheries were consolidated and asymmetries were reinforced. All this, of course, was to be expected, given the social and economic "deconstruction" I already alluded to. The present crisis, in short, is the culmination of these processes and therefore it looms as a major factor in social and political unsustainability. At the center of this scenario we find the huge imbalances brought about by the financialization of the economy and by the imposition of economic behaviors and logics having little or nothing to do with production, with wealth creation and its fair distribution, and most of all with the inclusive logic of development.

Therefore, if we say that the economy is a social system of provision and use, with wealth creation and individual and collective empowerment as its main goals, then the set of problems associated with the economy is bound to be different from the problems caused 
by deregulated financial rationality. Also required is an adequate interpretation of all the phenomena and processes facing us, as well as a thorough understanding of state-market relations. This is why, incidentally, it seems clear that the problem of wealth creation and distribution has to be brought back to the forefront of the priorities of the economy and economic organization. What we are talking about here is development strategies, and by strategies I mean resolute choices, the convergence of actions and means, and putting the common interest first. I mean social processes that are at once complex, composite, concerted, in short, that require an all-round approach.

One thing seems certain: nowadays, purely market mechanisms ("the markets!" that obscure, quasi-divine entity one constantly hears being invoked in everyday economic parlance) are not enough to restore growth and well-being. Suffice it to recall the radical way in which the fierce, speculative and financial appropriation of the so-called market logic took place, and also, as Mirowski (2010) rightly observes, the main reason why markets suffer from an "inherent vice": the tendency to undermine themselves.

This means that I think it appropriate, especially in the case of peripheral economies, to take topics that are illustrative of the need to reshape many of the state-society interrelations I have pointed out as important for the present discussion and put them on the agenda.

It seems clear that such concerns point to similar concerns regarding the kind of economic knowledge so widely propagated and reproduced over the last decades. I am among those who believe that mainstream economic theory was one of the major active factors at the root of the present crisis, namely by reason of the market theory it promoted. This is tantamount to saying that the crisis carries with it an irresistible invitation to a return to the pluralism of economic conceptions, which cannot but be accompanied by judicious views of economic organization and of the mechanisms at our disposal for promoting coordination among its agents.

That is why it is important to consider that the economy, in this sense of the word, does not have to do with the material and relational structures of markets, production and consumption alone, for it also encompasses institutions, decision cultures, behaviors, governance and the relational attitudes of economic and social actors (Reis, 2010: 227-232). In order to see how economic actors are coordinated and how the density of markets, state and community is formed, we need a broader economic paradigm than the one based on 
market rationality. The state "calibrates" the market's weaknesses while also establishing its scope: thus, for instance, when a EU-based international system was established, the state began to function as an agent for the geographical containment of the market's relational capacity.

\section{To fully understand the material role of the state, an institutionalist theory of the state and of society is required}

In order to fully understand the role of the state, it is certainly imperative that we tacitly assume the evolutionary nature of its performance. The liberal state, the welfare state, the neoliberal state and the new social state are evolutionary forms whose matrix and reason for being can be found in the tensions (made up of conflict and consensus) determining the various levels of collective dynamics. We also need a comparative institutional analysis based on a "varieties of capitalism" approach. Both approaches will no doubt help clarify the necessary relationship between the historical materialization of each state form and the particular conditions of each country. At the center of the institutionalist perspective is the notion that individuals are empowered by institutions by way of the contexts, references and standards made available to them by said institutions.

Whereas the historical nature of the state and of the roles it plays both in the economy and in society hardly needs to be emphasized, our perception of the ontology of the state is especially dependent on what we gather from the evolutionary view. I believe it is important to be aware of the fact that there is a clear parallel between the cumulative processes of material development, on the one hand, and the formation of the state as a structuring agent of those processes, on the other. Thus the configuration of the welfare state, for instance, cannot fail to be seen as strongly linked to the major phenomena which led to the transformation of capitalist societies that followed dynamic paths. Industrialization, wage relations, urbanization, or the development of redistributive mechanisms fostered by the growing collective capacity to generate wealth, have consolidated certain inescapable models of "progress" and defined non-reversible social standards. One could say that all this rests on mechanisms of a social or economic nature that are distinct from, and more powerful than, those of a political nature. In this sense, one could also concede that the nature of the state or its being termed as a social or welfare state is driven by material and 
collective evolution itself, that is, by the dynamics of the structures that shape society and society's interactions.

But it also seems clear - and this is what makes the state's relationship with the economy and society a complex one and brings to light the variety of phenomena involved in that relationship - that such a development of material life and social relations radically needs to be validated, consolidated and "formalized" from an institutional point of view. This, in turn, presupposes a role that only a structured, relatively autonomous entity like the state, with its legitimizing power and capacity, is in a position to provide. That is where the state's evolutionary nature shows it to be the institution that validates, legitimizes and instills cumulative meaning into that which society and the economy made possible through their own material and relational dynamics. Interrelationships and interdependence are therefore powerful.

Any interdisciplinary analysis will have to pay special attention to the social uses of the state rather than to its transcendent nature. The role of the state in producing norms and rules, together with its legitimizing function and with the very fact that it is an organization, that is, a locus where knowledge and skills are accumulated, all go to show that the state defines contexts for action as well as forms of collective behavior and individual well-being, that it establishes tight, complex networks, and that it has a major impact in terms of nonstate decisions and in the definition of social goals. In fact, the state is the institution-ofinstitutions. This makes it a highly material and relational entity, with an active role in processes whose boundaries are far from clear-cut.

As stated at the outset, emphasizing a view of the state as political, autonomous and disconnected from society seems of little use for our present purposes. In fact, it will be easier to comprehend the nature of the state if we consider its social uses and its profound interrelationship with a number of areas that should not be misconstrued as autonomous. We have seen that the validation of evolutionary forms generated by society is one of those uses, and a particularly relevant one at that, once we acknowledge that we are facing processes of a progressive nature, both materially and socially. The function of the state as a producer of rules and norms is therefore no mere abstract defining trait. On the contrary, the relevance of institutions vis-à-vis societies is measured by their role in the structuring of social interactions. 
Rules and norms, as well as implicit rules and, most of all, social norms are clear evidence of the state's institutional role. Hodgson (2006: 2) views institutions as "systems of established and prevalent social rules that structure social interactions," while according to North (2005: 1) institutions are "institutional constraints" that "cumulate through time" in such a way that "the culture of a society is the cumulative structure of rules and norms (and beliefs) that we inherit from the past that shape our present and influence our future."

The institutional dimension or structure thus requires that the following three critical aspects be understood: the accumulation of values over long processes, their validation in a way that is both legitimate and legitimizing, and the multifarious nature of these values, which in turn makes them not just into norms but also into culture. In such a context, one's perception of the state can only stand to gain from a conceptualization of institutions in the terms just described.

The normative dimension outlined above validates and establishes values, ideas, cultures - which is, first and foremost, what an institutional system is all about. This is why I have defined institutions as "collective consolidations of ways of understanding, of doing, and of organizing actions within society" (Reis, 2009: 20). Viewed in a broad, dynamic sense, certain institutions should also be regarded as entities endowed with a specific density as well as with a substantive weight and role in society, that is, as acting subjects. In addition to its consolidating and validating role as a legitimizing institution, the state is also a site of collective accumulation of knowledge and skills, and this is what delimits and characterizes it as an organization. The technical and organizational dimensions become especially relevant in functions such as those relating to administration, regulation, planning and supply. The technical state apparatus shows what else there is in the state besides its political nature. Such functions have to do with processes of intervention in the collective organization.

One of the aspects of the historical dynamics that may best illustrate the institutional nature of economic and social development, and therefore the state-economy relationship, is the emergence of the wage society. It seems fair to say that the critical issue here was the transition of wages from a category embedded in relations of personal dependency to the category of "economic" variable. While at that early stage labor markets functioned as highly asymmetrical "private" contexts, with the advent of industrial society the nature of that variable was to change radically. Wages are then no longer seen as mere compensation for work, but start to be regarded as a core relationship, both economically and politically. The 
dual nature of wages - at once cost and income - would soon be associated with another dimension, that of direct and indirect wages. The fact that it is a cost is indicative of a strengthening of the relationship between wages and productivity. The latter is directly linked not only to microeconomic and organizational conditions in the firm but also to competences and skills (e.g. education, health, mobility, being part of a network of social relations) that the worker did not get from his employer but are rather dependent on previous public decisions and on the assurance that collectively accessible forms of provision are in place. Apart from this relationship, which may be measured in microeconomic terms, the ability of enterprises to afford certain costs is also dependent on the contextual value of the goods or services they provide. That, in turn, is linked to the positive externalities they may benefit from - be they infrastructural, information, knowledge or merely contextual externalities.

But what truly underscores the economic, public and collective nature of the relation on which wages are based is the fact that they are also an income, by means of which most citizens shape their own demand and affirm their belonging to society as a whole. Their impact and overall influence become macroeconomic and macrosocial, and of course political as well. This is primarily because wages are linked to a society's global dynamics, from growth to well-being. This has to do with the fact that in such societies the wage relation does not limit itself to direct wages alone, that is, to the immediate monetary relationship between worker and employer. Aside from the fact that this relationship includes a contractual dimension involving rights and obligations (which in and of themselves also determine levels of indirect wages), what ultimately defines indirect wages are public policies and the state's intervention with regard to its citizens' income, an intervention based on the assumption that the labor market is a powerful mechanism for social inclusion.

For these reasons, the wage relation went from being a private production-based economic relationship to being a social relationship of a public nature, on which, moreover, a new historical phase was founded, marked not just by industrialization and wage relations but also by urbanization, the advancement of knowledge and the centrality of collective organization.

The economic constitutions of industrialized nations and the labor democracies that evolved in their midst until the abrupt wage deflation caused by the crisis that erupted in 
2008 are but concrete manifestations of what has just been said. If we consider the relationship between direct and indirect wages, as well as each and every form of public policy relating to workers' conditions, we may rightly ask: how much is there of public policy in the retribution paid to wage earners? The transition of wages from a simple individual relationship to sector-based agreements and on to general wage norms and to minimum labor standards shows the presence of a number of different, if interconnected, processes.

\section{To conclude: Institutionalist and relational exercises on the state and the market (and the} world's turbulence)

National differences notwithstanding, the role of the state in contemporary societies is the outcome of a long relational process. This process is marked by relevant social phenomena and by crucial problems regarding collective organization, as well as by the effect of the actual institutional solutions that establish and delimit the role of the state in each society. The political nature of the state and the institutional consolidation it entails are intimately linked to the logic of conflict and compromise inherent in social phenomena and social dynamics.

Both fields - relational phenomenology and the institutional validation of solutions and forms of intervention - are indicative of questions that are intrinsically process-related and historical. Let us return to the examples submitted above with regard to urbanization and industrialization. What we have is collective circumstances for building social processes that are expressive of dimensions of material life which give rise to institutional configurations in the present instance, of the state type. The place of collective processes in the overall social organization can be reconstructed from a great variety of points of departure. It is important, however, to correctly interpret the circumstances facing us in the real world. Reductive solutions will inevitably lead to problems of disciplinary consistency, as shown these days by economics. Indeed, by reducing itself to a discipline devoted to the study of markets, economics has critically undermined its scholarly nature as well as its ability to interpret social evolution, while also being responsible for "colonizing" the public sphere with controversial ideas. Hence the usefulness of an "indisciplinary" view that brings us closer to social processes and phenomena in all their complexity and entirety.

Translated by João Paulo Moreira

Revised by Teresa Tavares 


\section{References}

Buchanan, James (1986), Liberty, Market and State: Political Economy in the 1980s. Brighton: Wheatsheaf Books.

Buchanan, James (1991), Constitutional Economics. Oxford/Cambridge: Basil Blackwell.

Chang, Ha-Joon (2001), "Breaking the Mould: An Institutionalist Political Economy Alternative to the Neoliberal Theory of the Market and the State," Social Policy and Development Programme Paper 6. New York: UN Research Institute for Social Development. Available at http://www.unrisd.org/unrisd/website/document.nsf/d2a23ad2d50cb2a280256eb300385855/44 552a491d461d0180256b5e003cafcc/\$FILE/chang.pdf

Chang, Ha-Joon (2007), "State-Owned Enterprise Reform", Policy Notes. New York: United Nations, Department for Economic and Social Affairs, National Development Strategies. Available at http://esa.un.org/techcoop/documents/pn soereformnote.pdf

Chang, Ha-Joon; Nolan, Peter (1995), "Europe versus Asia - Contrasting Paths to the Reform of Centrally Planned Systems of Political Economy", in Ha-Joon Chang and Peter Nolan (eds.), The Transformation of the Communist Economies: Against the Mainstream. London/Basingstoke: Macmillan.

Furubotn, Eirik G.; Richter, Rudolf (2001), Institutions and Economic Theory: The Contribution of the New Institutional Economics. Ann Arbor: The University of Michigan Press.

Galbraith, John Kenneth (1998), The Affluent Society. New York: Mariner Books/Houghton Mifflin. [1 ${ }^{\text {st }}$ ed.: 1958].

Galbraith, John Kenneth (1968), The New Industrial State. New York: The New American Library. [1 ${ }^{\text {st }}$ ed.: 1967]

Hall, Peter; Soskice, David (2001), Varieties of Capitalism. The Institutional Foundations of Comparative Advantage. Oxford: Oxford University Press.

Hirschman, Albert (1991), The Rhetoric of Reaction: Perversity, Futility, Jeopardy. Cambridge, MA: The Belknap Press of Harvard University Press.

Hodgson, Geoffrey (2006), “What Are Institutions?” Journal of Economic Issues, XL(1): 1-25.

Hollingsworth, J. Rogers; Boyer, Robert (1997), "Coordination of Economic Actors and Social Systems of Production," in J. Rogers Hollingsworth and Robert Boyer (eds.), Contemporary Capitalism: The Embeddedness of Institutions. New York/Cambridge: Cambridge University Press, 1-47.

Jackson, Gregory; Deeg, Richard (2006), "How Many Varieties of Capitalism? Comparing the Comparative Institutional Analyses of Capitalist Diversity", MPIfG Discussion Paper 06/02. Cologne: Max Plank Institute for the Study of Societies. Available at http://www.mpifg.de/pu/mpifg dp/dp06-2.pdf

Mamede, Ricardo Pais (2009), "Os desafios do desenvolvimento económico e o papel das políticas públicas," in Renato Miguel Carmo; João Rodrigues (eds.), Onde pára o Estado. Lisboa: Edições Nelson de Matos.

Mirowsky, Philip (2010), "Inherent Vice: Minsky, Markomata, and the Tendency of Markets to Undermine Themselves," Journal of Institutional Economics, 6(4): 415-443.

Neves, Vítor (2004), "Situational Analysis Beyond 'Single-exit' Modelling," Cambridge Journal of Economics, 28(6): 921-936.

North, Douglass (2005), Understanding the Process of Economic Change. Princeton: Princeton University Press. 
Pereira, Paulo Trigo (1997), “A teoria da escolha pública (public choice): uma abordagem neoliberal?” Análise Social, 141: 419-442.

Polanyi, Karl (1957), The Great Transformation. Boston: Beacon Press.

Reis, José (2001), “A globalização como metáfora da perplexidade? Os processos geoeconómicos e o 'simples' funcionamento dos sistemas complexos," in Boaventura de Sousa Santos (ed.), Globalização: fatalidade ou utopia? Porto: Edições Afrontamento, 109-134.

Reis, José (2009), Ensaios de economia impura. Coimbra: Almedina/CES.

Reis, José (2010), "Um ciência indisciplinar: a cidade dos economistas," in Vítor Neves and José Castro Caldas (eds.), A economia sem muros. Coimbra, Almedina/CES.

Reis, José (2012), “Um exercício interdisciplinar: identificar o lugar do Estado na economia," in Celia Lessa Kerstenetzky and Vítor Neves (eds.), Economia e interdisciplinaridade(s). Coimbra, Almedina/CES.

Reis, José; Nunes, João Arriscado (1993), "Albert O. Hirschman: a propósito de The Rhetoric of Reaction," Notas Económicas - Revista da Faculdade de Economia da Universidade de Coimbra, 1: 108-112.

Rodrigues, João (2009), "Onde pára o mercado: movimentos e contramovimentos nas políticas públicas," in Renato Miguel Carmo and João Rodrigues (eds.), Onde pára o Estado. Lisboa: Edições Nelson de Matos.

Rodrik, Dani (2008), "Second-Best Institutions." NBER Working Paper no. 14050. Available at the National Bureau of Economic Research website: http://www.nber.org/papers/w14050

Smith, Adam (2011), The Theory of Moral Sentiments. New York: Empire Books [1st ed.: 1759].

Stiglitz, Joseph (1999), "Whither Reform? Ten Years of the Transition." Keynote Address, Annual Bank Conference on Development Economics, Washington. Available at http://siteresources.worldbank.org/DEC/Resources/84797-1251813753820/6415739$\underline{1251814010799 / \text { stiglitz.pdf }}$ 